\title{
Tingkat Partisipasi Masyarakat Lokal Dalam Pengembangan Kampung Wisata Kreatif Dago Pojok Di Kota Bandung
}

Agnes Anggi Hasian Silaban a,1 Gde Indra Bhaskara ${ }^{\mathrm{a}, 2}$

1agnesanggihs@gmail.com² gbhaskara@unud.ac.id

a Program Studi S1 Destinasi Pariwisata, Fakultas Pariwisata,Universitas Udayana, Jl. Dr. R. Goris, Denpasar, Bali 80232 Indonesia

Abstract

A creative tourism is a form of sustainable tourism that offers authentic experiences of local culture. Tourism activities that have been running for about 9 years in Dago Pojok Creative Village, sparked researchers attention identify the condition of tourism and measuring level of local community participation in the development of Dago Pojok Creative Tourism Village.

This study aims to identify tourism conditions and level of participation of local communities in the development of Dago Pojok Creative Tourism Village. The types of data used are qualitative and quantitative data with observation, interview and document data collection. Analysis of the data used is descriptive-qualitative data analysis using the concept of tourism components and the theory of a ladder of citizen participation.

The results of this study show that the condition of tourism which is reviewed through the components of tourism products (4A) in Dago Pojok Creative tourism village recently is sufficient enough to improve some of the existing facilities. The level of community participation in Dago Pojok Creative Tourism Village is at the first level in the theory of a ladder of citizen participation.

Based on the results, local communities have participated in the development of tourist attractions neverheless but it is still constrained by the government who expects the community itself to develop the tourist village without government assistance. On the contrary, local people expect assistance from the government.

Keyword: participation, rate, community, creative, village.

\section{PENDAHULUAN}

Pemerintah pusat berupaya mengembangkan pariwisata berbasis pada potensi dan kemampuan masyarakat dalam mengelola kegiatan pariwisata. Para pemangku kepentingan pariwisata dituntut mampu bersinergi untuk dapat mewujudkannya. Portofolio produk pariwisata oleh Kementerian Pariwisata RI menyatakan alam sebesar 35\%. budaya $60 \%$ dan man made 5\% (Mahagangga, 2018).

Pariwisata kreatif merupakan bentuk pariwisata berkelanjutan yang menawarkan pengalaman otentik budaya lokal dan pengalaman kreatif. Faktanyam potensi wisata alam, potensi wisata budaya dan potensi wisata buatan dapat disinergikan berdasarkan skala prioritas dan kemampuan pengelolaan suatu destinasi wisata.

Kota Bandung, Provinsi Jawa Barat merupakan rumah 2,5 juta penduduk Indonesia. Faktanya, 56\% kegiatan di bidang ekonominya terkait dengan desain, fesyen, desain grafis, dan media digital. Bandung Creative City Forum (BCCF) merupakan salah satu program yang diselenggarakan untuk tujuan membina jaringan kota-kota kreatif dan membahas pembangunan kota yang berkelanjutan dengan berbagi ide yang inovatif.

Pemerintah Kota Bandung mendorong pembangunan Kampung Kreatif. Pembangunan Kampung Kreatif mendorong terciptanya kampung yang penuh aktivitas seni budaya sehingga meningkatan perekonomian masyarakat lokal serta dapat mempertahankan budaya daerah secara berkelanjutan. Kemunculan kota kreatif sejalan dengan perkembangan ekonomi kreatif. Kota Bandung memiliki beberapa daya tarik wisata yang mendukung ekonomi kreatif yaitu terdapatnya beberapa kampung kota yang ditetapkan sebagai kampung kreatif di Kota Bandung. Adapun kelima kampung wisata tersebut yaitu, Kampung Taman Musik, Kampung Kreatif Cicukang, Kampung Wisata Akustik dan Kampung Kreatif Pasundan serta salah satunya Kampung Kreatif Dago Pojok.

Pembentukan kampung kreatif merupakan kerjasama antara komunitas Taboo Dago Pojok dan Bandung Creative City (BCC). Komunitas Taboo Dago Pojok merupakan komunitas yang bergerak di bidang program pembangunan kota. Kampung kreatif dago pojok adalah kampung kreatif pertama di Kota Bandung dan dikembangkan sejak tahun 2009 oleh Rahmat Jabaril dan komunitas Taboo Dago Pojok. Berbagai produk sudah dihasilkan oleh Kampung Kreatif Dago Pojok diantaranya adalah kesenian khas Sunda mulai dari tarian, musik dan permainan tradisional. Bertujuan untuk mengembangkan sektor perekonomian masyarakat, mengembangkan potensi yang dimiliki oleh masyarakat baik dalam bidang seni, budaya, dan menghasilkan suatu produk.kerajinan khas atau aktifitas berbasis budaya.

Aktor yang memiliki peran penting dalam pengembangan pariwisata di Kampung Kreatif Dago Pojok adalah masyarakat lokal karena masyarakat lokal adalah orang yang akan berinteraksi secara langsung dengan wisatawan. Selain dukungan dari 
pemerintah, partisipasi masyarakat lokal sebagai wujud kontribusi bagi penyelenggaraan dan pengembangan pariwisata di Dago Pojok juga diperlukan untuk menjaga eksistensi pariwisata Dago Pojok yang telah berkembang selama kurang lebih 9 tahun. Aktivitas pariwisata yang sudah berjalan cukup lama di Kampung Kreatif Dago Pojok, membuat peneliti tertarik untuk mengukur sejauh mana tingkat partisipasi masyarakat lokal dalam pengembangan Kampung Wisata Kreatif Dago Pojok.

\section{TINJAUAN PUSTAKA}

Adapun beberapa telaah penelitian sebelumnya yang berkaitan dengan penelitian ini yang pertama oleh Paramita (2015) terkait motif dan partisipasi masyarakat. Kemudian oleh Marysya (2017) terkait partisipasi masyarakat untuk keberhasilan mengembangakan suatu kawasan desa wisata. Penelitian terakhir oleh Murdiyanto (2011) terkait tingkat partisipasi masyarkat melalui tiga pendekatan.

Untuk menganalisis permasalahan dalam penelitian ini menggunakan berberapa konsep diantaranya, konsep partisipasi masyarakat lokal (Sumaryadi 2010), konsep daya tarik wisata (Cooper 1998), konsep pengembangan (Paturusi dalam Padabain 2017), konsep kampung kreatif (Patton dan Subanu 1998) dan teori tingkat partisipasi (Chougil 1996).

\section{METODE PENELITIAN}

Penelitian ini dilakukan di Kampung Kreatif Dago Pojok, berada di Jalan Dago Pojok RT 2 RW 3, Kelurahan Dago, Kecamatan Coblong, Kota Bandung, Jawa Barat. Ruang lingkup penelitian digunakan untuk memperjelas arah dan batasan permasalahan. Berdasarkan rumusan masalah yang sudah dipilih maka yang menjadi fokus permasalahannya adalah tingkatan partisipasi masyarakat dalam mengembangkan Kampung Wisata Kreatif Dago Pojok yaitu, partisipasi masyarakat lokal, partisipasi pemerintah, partisipasi Non Government Organization (NGO), kemudahan maupun kesulitan dalam menjalankan aktivitas pariwisata, dan manfaat dari aktivitas pariwisata di Kampung Kreatif Dago.

Jenis data yang digunakan adalah data kualitatif dan kuantitatif dengan sumber data primer dan sekunder. Teknik pengumpulan data dalam penelitian ini dengan cara observasi, wawancara dan dokumen. Dimana teknik penentuan informan melalui purposif sampling. Teknik analisis data yang digunakan adalah teknik analisis data deskriftif kualitatif (Miles dan Huberman dalam Sugiyono, 2012)

\section{HASIL DAN PEMBAHASAN}

Pada tahun 1960-1980, daerah Dago Pojok dihuni oleh pelaku kesenian, seperti dalang dan pengrajin alat musik seni kerawitan. Menjelang tahun 1990-2000, sebagian besar penduduk daerah ini beralih profesi sebagai buruh bangunan. Pada era itulah keadaan daerah semakin memburuk. Banyak tindakan kriminal yang terjadi yang dilakukan oleh pendatang dan mereka bersikap individualis. Pada tahun 2010, seorang Rahmat Jabaril selaku masyarakat Kota Bandung yang peduli akan seni dan budaya melihat potensi yang ada pada daerah terpencil di pusat kota. Beliau adalah seorang pendiri komunitas Taboo. Komunitas Taboo merupakan komunitas rumah baca yang mewadahi anak-anak yang putus sekolah di kampung tersebut.

Gerakan awal yang telah dilakukan oleh Komunitas Taboo adalah meningkatkan standar pendidikan masyarakat dengan membangun pendidikan informal gratis pada tahun 2003. Pada saat program ini berjalan, kemajuan menunjukkan kepuasan yang signifikan, tidak hanya berhasil menjalankan visinya menuju peningkatan kualitas pendidikan masyarakat Dago Pojok, Komunitas Taboo telah berhasil memunculkan potensi lain di masyarakat.

1. Kondisi Pariwisata Kampung Kreatif Dago Pojok

a. Atraksi

Mural merupakan atraksi utama yang ditawarkan di Kampung Wisata Kreatif Dago Pojok. Dimana setiap dinding rumah masyarakat lokal dan dinding-dinding sekitar permukiman kampung wisata kreatif ini. Terdapat mural di setiap gang. Mural tersebut merupakan wujud karya masyarakat lokal Dago Pojok dalam hal apresiasi seni dan kreativitas. Wisatawan yang datang berkunjung akan disajikan keindahan cat warna-warni yang mengelilingi kampung. Hal ini tentunya menjadi nilai jual yang cukup baik, diman kampung wisata lain sejenis belum ada yang menyuguhkan hal seperti ini. Proses inilah yang kemudian disebut proses kreatif, dimana wisatawan bisa menumpahkan kreativitas mereka sebuah objek bernama dinding.

Kesenian yang ditawarkan di Kampung Wisata Kreatif Dago Pojok sangat beragam dengan terus menjaga eksistensi dari kesenian-kesenian lokal Sunda agar tetap bertahan dan tidak hilang. Kesenian-kesenian tersebut yaitu kesenian pencak silat, jaipongan, degung, kuda lumping, karinding, dan calung. Pencak silat sendiri dilakukan oleh anak-anak yang ada diwilayah kampung. Kegiatan pelatihan biasanya dilakukan sekali seminggu. Jaipongan dilakukan oleh anak-anak maupun orang dewasa. Pelatihan jaipongan dilakukan juga sekali seminggu.

Setiap tahunnya, Kampung Wisata Kreatif Dago Pojok mengadakan event tahunan. Beberapa event 
tersebut yaitu, Festival Ulubiung (Festival Seni Tatar Sunda), Pameran Seni Rupa "Seni Partisipasi dan Partisipasi Seni", Bazar Murah yang dikemas dengan adanya acara hiburan berupa pertunjukan seni, menjual kerajinan dan menjual jajanan kampung dan Hakiking Budaya. Workshop merupakan atraksi wisata yang ditawarkan bila di Kampung Wisata Kreatif Dago Pojok sedang mengadakan event besar atau sudah adanya pemesanan yang dilakukan wisatawan sebelum mengunjungi Kampung Wisata Kreatif ini. Adapun workshop yang sudah pernah dilakukan di Kampung Wisata Kreatif Dago Pojok sebagai berikut, Workshop Jajanan Sunda , Workshop Patung, Pertunjukan Teatrikal Marat dan lain sebagainya.

Sanggar wayang golek yang terdapat $\mathrm{di}$ Kampung Wisata Kreatif Dago Pojok diberi nama Galeri Astina. Galeri Astina sendiri pada awalnya saat Dago Pojok disahkan sebagai Kampung Wisata Kreatif tahun 2011, sanggar ini hanya berupa rumah salah satu masyarakat yang seiring berjalannya waktu berubah menjadi galeri dan kemudian dijadikan sanggar dengan bantuan dari berbagai pihak.

Setiap minggunya di sanggar ini selalu melakukan kegiatan. Baik mengisi acara diluar maupun latihan sekali seminggu. Tak hanya menampilkan pertunjukan wayang golek saja, anggota sanggar pun telah membuat suatu produk dari bahan dasar sampah kayu dijadikan sebuah produk yang sangat menarik dengan ukiran wayang golek yang khas.

Produk kerajinan tangan ini berupa pulpen dan gantungan kunci. Harga satuan dari produk pulpen seharga Rp. 20.000 per pulpen dan gantungan kuncinya seharga Rp. 15.000 per satuannya. Produksi pulpen dan gantungan kunci ini tidak terlalu banyak. Wisatawan yang datang berkunjung dapat membelinya jika produknya ada saja.

Galengan Sora Awi merupakan grup binaan Bapak Akim. Grup musik ini adalah grup musik yang memainkan instrumen sunda otentik. Jenis alat musik yang digunakan dalam pertunjukan musik ini merupakan alat musik yang sepenuhnya terbuat dari bahan utama bambu. Adapun diantaranya yaitu, celempungan, karinding, keprak dan guludug.

Terdapat beberapa jenis permainan yang sering dimainkan di Kampung Wisata Kreatif ini saat wisatwan berkunjung yaitu, pepletokan adalah sebuah permainan senjata yang terbuat dari bahan dasar bambu yang pelurunya terbuat dari kertas yang dibasahkan. Mereka yang memainkan permainan ini seolah-olah sedang berada di dalam sebuah pertempuran. Selanjutnya adalah perepet jengkol yang merupakan lagu permainan sunda yang dinyanyikan oleh tiga orang laki-laki atau tiga orang perempuan dengan saling memegang tangan dan membelakangi temannya masing-masing, kaki kanan diangkat sampai ke betis dan disilangkan ke teman dengan kuat sehingga berbentuk seperti anyaman. Masing-masing tangan dilepaskan kemudian meloncat-loncat kearah kiri sambil bertepuk tangan mengikuti irama lagu. Terakhir adalah permainan galah jidar merupakan permainan individual dengan menggunkan bambu atau kayu sebagai penggaris untuk membuat jarak yang akan dilompati. Inti dari permainan ini adalah harus melewati jarak yang menjadi rintangan untuk dilompati dengan jumlah langkah sesedikit mungkin, karena semakin lama jaraknya semakin jauh.

b. Fasilitas

Di Kampung Wisata Kreatif Dago Pojok sudah terdapat akomodasi yang cukup memadai. Tersedianya homestay bagi wisatawan yang ingin menginap, warung penjual makanan, masjid, lahan parkir dan panggung pementasan di lapangan. Kampung Wisata Kreatif Dago Pojok sudah memiliki empat buah homestay.

Lapangan di kampung Wisata Kreatif terletak di RT 02 RW 3. Di lapangan tersebut terdapat sebuah panggung pementasan dimana saat diadakannya pertujukan, workshop atau acara lainnya panggung ini dapat digunakan menampung wisatawan yang menonton. Kampung Wisata Kreatif juga telah menyediakan paket wisata ke kampung ini dengan nama program open trip. Paket wisata ini mulai dijalankan sejak tahun 2011 dengan kegiatan yang dilaksanakan seminggu sekali. Wisatawan akan diajak mengelilingi kampung, melihat masyarakat lokal berlatih kesenian dan membuat kerajinan serta bermain bersama anak-anak. Namun semenjak awal 2016, program open trip berubah dengan tiga jenis paket wisata.

Paket wisata pertama yaitu, penginapan, wisatawan menyaksikan pertunjukan berupa dapat memilih seni-seni tradisional sunda, dan mengikuti workshop berupa dapat memilih melukis atau membuat wayang, puzzle, melukis kaos, seni kolase, seni ukir dan batik serta adanya diskusi. Paket wisata yang kedua adalah wisatawan tanpa menginap, menyaksikan pertunjukan dan mengikuti workshop dengan adanya diskusi. Kemudian paket wisata yang ketiga ialah workshop saja ditambahi dengan adanya diskusi. Informasi terkait pemesanan paket wisata ini dapat dilakukan dengan mengunjungi akun media sosial Kampung Wisata Kreatif yaitu di instagramnya @kampungkreatifdagopojokbdg atau dapat langsung mencari informasinya di mesin pencarian google. Kampung Wisata Kreatif juga sudah memiliki lahan parkir dikampus UNPAD yang berada dekat wilayah kampung wisata tersebut.

c. Aksesibilitas

Kampung Wisata Kreatif Dago Pojok merupakan daya tarik wisata yang terletak di tengah pusat kota. 
Jarak tempuh menuju Kampung Wisata Kreatif Dago Pojok dari Bandara Husein Sastranegara sejauh 9,1 $\mathrm{km}$ atau sekitar 21 menit dalam kondisi lalu lintas lancar. Oleh karena itu, akses menuju Kampung Wisata Kreatif Dago Pojok dapat dituju menggunakan kendaraan umum beruapa angkutan kota dan angkutan online. Dapat pula menggunakan kendaraan pribadi baik kendaraan roda empat maupun roda dua.

Kondisi jalan utama menuju Kampung Wisata Kreatif dago Pojok sudah baik dan lalu lintas cukup kondusif. Namun, jika ingin menuju Kampung Wisata ini dapat menggunakan angkutan umum, wisatawan harus berjalan lagi sejauh $1 \mathrm{KM}$ ke dalam gang. Jalanan pada gang menuju Kampung Wisata Kreatif ini banyak yang sudah tidak bagus lagi, bahkan papan petunjuk mengenai Kampung Wisata tidak ada. Berdasarkan hasil wawancara kepada Kang Rahmat selaku penggagas Kampung Wisata Kreatif, beliau mengatakan "Dulu memang ada papan petunjuknya, namun sekarang sudah rusak dan masih belum diganti lagi". Berdasarkan observasi di lapangan, pappan petunjuk yang menunjukan bahwa itu Kampung Kreatif ditemukan berada di dalam gang kecil dan hampir tidak terlihat.

d. Pelayanan Tambahan

Kelembagaan di Kampung Wisata Kreatif ini berupa organisasi yang di bentuk pada tahun 2017. Berdasarkan wawancara langsung kepada Bapak Rahmat Jabaril, beliau mengatakan "Nah itu, struktur kepengurusan kampung kreatif tidak begitu aktif yang sekarang, karena sebagian sudah pada pindah rumahnya, karena sudah pada nikah." Berdasarkan hal tersebut, dapat disimpulkan bahwa organisasi pengelolaan kampung wisata kreatif ini semakin memburuk. Tak hanya organisasi ini saja yang ada di kampung wisata ini, melainkan mereka ada dibawah pimpinan ketua RT 02. Terkait setiap pelaksanaan event besar, pelaksanaaannya bekerjasama dengan berbagai macam jenis kelembagaan lain seperti pemerintah kota, pemerintah desa dan komunitas-komunitas serta beberapa perguruan tinggi.

2. Tingkat Partisipasi Masyarakat Kampung Kreatif Dago Pojok

Pariwisata kreatif dipahami sebagai kegiatan kepariwisataan yang melibatkan interaksi dari pendatang, sehingga pendatang dapat belajar, berhubungan secara emosional, sosial, dan interaksi partisipatif dengan tempat, budaya, dan masyarakat lokal. Wisatawan dalam konteks pariwisata kreatif secara tidak langsung maupun langsung akan menjadi bagian dari mayarakat lokal dari destinasi yang dikunjungi, baik secara fisik maupun secara ide. Wisatawan di Kampung Wisata Kreatif Dago Pojok sendiri dapat belajar dari masyarakat dan sekaligus bisa berkolaborasi untuk menghasilkan suatu produk kerajinan atau desain baru tentang pola pembelajaran, pengetahuan mengenai kesenian dan sebagainya.

Dalam proses pengembangannya, masyarakat lokal menjadi sumber utama dalam pengambilan keputusan. Wisatawan merupakan modal utama dalam pengembangan suatu destinasi pariwisata, namun dalam konteks pariwisata kreatif wisatawan harus bekerja sama dengan masyarakat lokal dalam pengembangan destinasi wisata kreatif itu sendiri. Diperlukannya sumber daya manusia yang juga kreatif dan inovatif dalam pengelolaannya agar daya tarik wisata tersebut dapat terus menjaga eksistensiannya.

Tingkatan partisipasi masyarakat dilakukan bertujuan untuk mengetahui tingkat partisipasi masyarakat sudah berada di tingkatan mana. Berdasarkan hasil penelitian di lapangan maka akan ditarik kesimpulan mengenai daya tarik wisata Kampung Kreatif Dago Pojok sudah berada di tingkat yang mana berdasarkan delapan tingkatan partisipasi masyarakat yang sudah dipaparkan pada bab dua.

a. Partisipasi Masyarakat Lokal

Konsep Kampung Wisata Kreatif awalnya diusulkan oleh Rahmat Jabaril sebagai pengagasnya kepada ketua RW yang kemudian disetujui dan dilakukan sosialisasi kepada seluruh masyarakat wilayah Dago Pojok. Usulan tersebut dilakukan karena Rahmat Jabaril merasa bahwa masyarakat lokal memiliki pengetahuan lebih tentang kekayaan budaya yang menjadi hal utama dalam pengembangan kampung wistaa kreatif berbasis masyarakata lokal. Sosialisasi yang dilakukan kepada masyarakat lokal diberikan untuk memberi pemahaman mengenai bagaimana masyarakat lokal mengenal potensi wisata yang dapat dikembangkan di wilayah Dago Pojok. Masyarakat lokal dapat pula berperan dalam pengembangan program yang nantinya akan memberikan dampak positif bagi wilayah mereka. Kampung Wisata Kreatif ini dibangun dengan tujuan agar tanah yang ada di kampung tidak dijual dan menjadi habis perekonomiannya, serta budayanya akan hilang. Berdasarkan sosialisasi yang telah dilakukan tersebut, masyarakat Dago Pojok sebagian besar menyambut baik adanya Kampung Wisata Dago Pojok, mereka berharap kedepannya kampung wisata ini dapat mendongkrak perekonomian mereka.

Adapun kegiatan wisata yang dapat dilakukan di kampung wisata ini bersumber dari aktivitas masyarakat lokal. Daya tarik wisata yang paling menonjol dari kampung wisata kreatif adalah kesenian tradisionalnya. Kegiatan wisata yang ada di kampung wisata ini tidak memberi paksaan atau tanggung jawab kepada masyarakat lokal apakah mereka ingin berpartisipasi mendukung kegiatan wista itu atau tidak. 
Masyarakat lokal menentukan sendiri terlibat atau tidaknya mereka. Masyarakat diberikan kebebasan berpartisipasi sesuai dengan kemampuan dan kesediaan masyarakat. Bentuk partisipasi dapat terwujud karena adanya kesesuaian antara kemampuan masyarakat dengan konsep pembangunan dalam menggembangkan daya tarik tersebut. Masyarakat Kampung Wisata Kreatif memiliki beragam kemampuan di berbagai bidang seni. Kemampuan itu tidak semata-mata ada dan dibiarkan saja. Mereka berlatih setiap sekali seminggu untuk selalu mengasah kemampuan mereka. Keterlibatan masyarakat lokal kampung wisata ini sangat diperlukan mengingat bahwa kampung wisata ini menawarkan atraksi wisata berupa keahlian yang dimilik oleh masyarakat lokal dalam bidang seni dan budaya lokal mereka.

Berdasarkan hasil penelitian di lapangan, tidak seluruhnya masyarakat memiliki kemampuan dibidang kesenian maupun kerajinan tangan, sehingga masyarakat yang tidak memiliki kemampuan tersebut tidak ikut berpartisipasi dalam pertunjukan ataupun workshop seni yang diadakan. Namun, masyarakat yang tidak memiliki kemampuan tersebut juga tetap memberikan partisipasinya dalam bidang lainnya yang mendukung kegiatan pengembangan kampung wisata kreatif.

\section{b. Partisipasi Pemerintah}

Pengembangan suatu daya tarik wisata harus didorong dengan adanya keterlibatan pemerintah didalamnya. Pemerintah sebagai pendukung pembangunan daya tarik wisata baik secara moril maupun secara material. Berdasarkan wawancra kepada Penggagas dan Ketua RT kampung wisata kreatif, bahwa partisipasi pemerintah kepada kampung kreatif sudah dimulai sejak tahun 20032009. Rahmat Jabaril dan anggota Komunitas Taboo Dago Pojok melakukan pendekatan dimana beliau mendatangi para tokoh-tokoh besar yang sudah dipetakan sebelumnya kemudian melakukan rapat besar. Dimana dalam rapat besar tersebut, seluruh tokoh-tokoh tersebut sudah sejiwa dan kemudian menyepakati membuat kampung budaya kreatif.

Pada tahun 2010 kemudian kampung yang awalnya dinamakan sebagai kampung budaya kreatif ini di presentasikan ke pemerintah. Pada saat itu mereka mengundang wakil walikota untuk menyaksikan. Mereka tidak mengundang Walikota karena beliau memiliki pandangan yang berseberangan atau tidak sependapat. Rapat tersebiut mengundang Bapak Ayi Vivananda sebagai wakil walikota kota bandung dan mengundang pula ketua-ketua RW yang terdapat dikelurahan berdasarkan hasil presentasi itu, pemerintah menyambut dengan baik ide yang telah di presentasikan tersebut. Tetapi pemerintah saat itu hanya mendukung secara moril saja ungkap Pak Rahmat Jabaril saat diwawancara. Masyarakat mulai menata kampung dengan modal mereka sendiri dan mulai membuat mural disepanjang jalan yang rumahnya ingin digambarkan.

Pada tanggal 28 Oktober 2011 wilayah ini diresmikan sebagai Kampung Wisata Kreatif Dago Pojok oleh pemerintah Kota Bandung. Sejak peresmiannya, penggagas sudah merancang 5 tahunan program menjadi daya tarik wisata tersendiri yang mempunyai nilai hal-hal yang berkaitan dengan kepariwisataan. Pada tahun ini, kampung wisata ini mengadakan event besar dimana event tersebut akan diadakan setiap tahunnya. Event yang diadakan pada tahun 2011 berjalan dengan baik dan lancar dengan modal dari masyarakat. Kemudian pada tahun berikutnya, kampung wisata ini sudah tidak memiliki modal dalam pembuatan event dan akhirnya membentuk kerjasama dengan Dinas Kebudayaan dan Pariwista Kota Bandung. Pada tahun 2014, pemerintah mempercayai Kampung Wisata Kreatif Dago Pojok sebagai tempat destinasi Konferensi Asia Afrika. Diadakannya pameran di setiap gang berupa pameran seni rupa dan karniuval.

Selanjutnya di tahun 2015 Kampung Wisata Kreatif Dago Pojok dipercaya oleh KPK membuat festival antikorupsi sedunia yang kemudian mendapatkan penghargaan dari KPK tersebut. Pada tahun berikutnya di tahun 2017, kampung wisata ini meniadakan event atau festival yang kemudian berlanjut ke tahun tahun berikutnya yaiu tahun 2018. Kampung Wisata Kreatif Dago Pojok bekerjasama dengan pemerintah daerah dalam acara seni rupa gang.

Berdasarkan pemaparan yang sudah dijelaskan diatas, dapat diambil bahwasanya pemerintah cukup sering mengadakan kerjasama dengan Kampung Wisata Kreatif Dago Pojok ini. Mulai dari pemerintah pusat, pemerintah kota maupun pemerintah daerah. Namun dalam seiring waktu, keterlibatan pemerintah diharapkan lebih banyak lagi dan tidak hanya mendukung dalam hal moril saja melainkan dalam hal material berupa pemberian dana agar Kampung Wisata Kreatif Dago Pojok dapat meningkatkan kualitas program yang ditawarkan dan dalam hal memperbaiki fasilitas serta untuk menjaga Kampung Wisata Kreatif Dago Pojok agar tetap berkelanjutan.

c. Partisipasi Non Goverment Organization

Partisipasi Non Goverment Organization (NGO) sudah ada sejak sebelum Kampung Wisata Kreatif Dago Pojok didirikan. Komunitas pertama yang melakukan kerjasama dengan kampung wisata ini adalah komunitas Taboo yang diketuai oleh Rahmat Jabaril. Komunitas Taboo merupakan komunitas rumah baca yang mewadahi anak-anak putus sekolah di wilayah Dago Pojok. Kerjasama dengan 
komunitas ini kemudian mampu membawa wilayah ini menjadi kampung wista kreatif.

Semenjak peresmiannya di tahun 2011, keterlibatan yang terjalin dengan Non Goverment Organization (NGO) sudah banyak dilakukan. Kerjasama yang dilakukan ada beragam bentuknya. Bentuknya lebih banyak mengarah pada berbagi ilmu kepada masyarakat dan wisatawan. beberapa diantaranya yaitu dengan perguruan tinggi negeri Universitas Padjajaran dalam bentuk kerjasama berbagi ilmu dalam pembuatan pupuk. Selanjutnya kerjasama yang dilakukan dengan mahasiswa Intitute Technology Bandung. Bentuk kerjasama yang dilakukan yaitu seniman asal ITB tersebut menggambar mural di wilayah Kampung Wisata Kreatif. Dimana mereka selalu dilibatkan setiap tahunnya dalam pembuatan mural karena setiap satu tahun sekali konsep mural yang ada di Kampung Wisata Kreatif berganti agar tidak memberi kesan membosankan. Kerjasama dengan sekolah internasional di Jakarta yaitu Cikal datang ke Kmapung Wisata Kreatif dago Pojok untuk mengadakan kegiatan berupa workshop dan berbagi ilmu kepada masyarakat lokal.

Kerjasama yang sudah pernah dilakukan selanjutnya adalah dengan komunitas Bandung In Your Hand. Bentuk kerjasama yang dilakukan dengan komunitas ini berupa sebuah aplikasi augmented reality. Aplikasi tersebut merupakan aplikasi yang dapat menampilkan informasi mengenai karya seni yang telah dibuat tersebut. Teknologi ini hanya terdapat pada beberapa karya seni saja. Selanjutnya kerjasama yang dilakukan adalah dengan beberapa stasiun radio seperti 99ers100 FM Bandung dan Oz Radio Bandung. Bentuk kerjasama yang dilakukan yaitu stasiun radio sebagai media promosi tyang menyiarkan adanya Kampung wisata Kreatif sebagai tempat yang dapat dikunjungi oleh siapapun jika tertarik mempelajari seni, budaya dan kerajinan khas lokal Sunda.

Komunitas lainnya yang pernah bekerjasama antara lain komunitas bernama Darah Rouge dan Komunitas Gerakan Pemuda Salarea. Bentuk kerjasama yang dilakukan dengan Kampung wisata Kreatif Dago Pojok adalah berupa mengadakan workshop maupun pameran seni rupa. Adanya partisipasi Non Goverment Organization (NGO) di kampung wisata kreatif adalah sudah banyak NGO yang melakukan kerjasama dengan kampung wista ini. Kerjasama ini tentunya membawa dampak positif untuk keberlangsungan aktivitas wistaa yang ada di kampung wisata ini agar tetap terjaga eksistensinya. Kemudian dengan adanya kerjasama, karena kampung wisata ini dibangun untuk pariwisata interaktif yaitu adanya interaksi antara host and guest dan konsep pembangunan kampung wisata ini adalah wisata edukasi, maka kerjasama dengan NGO sangan perlu dilakukan. Kerjasama dengan NGO pun harus dipilih sesuai dengan konteks berbagi ilmu mengenai seni dan budaya masyarakat lokal kampung wisata ini.

d. Hambatan dalam Menjalankan Aktivitas Pariwisata di Kampung WisataKreatif Dago Pojok

Pengembangan suatu destinasi pariwisata baik yang baru dikembangankan maupun yang sudah berjalan cukup lama tentu saja mengalami hambatan dalam mejalankan aktivitas pariwisata di dalamnya. Melalui wawancara kepada Ketua RT02 Bapak Aceng mengatakan "Kesulitannya dalam mengembangkan kampung wisata kreatif kita harus memahami dahulu bagaimana masyarakatnya, mereka tidak langsung menerima, kita harus merintis dulu dari 2002 dan pemerintah hanya memberi tamu tanpa adanya banttuan finansial. Pemerintah kota sering bawa tamu kesini. Berharap ada bantuan finansial dari pemerintah. Pemerintah hanya sekedar memberi tamu tanpa memberi bantuan.".

Sementara itu berdasarklan hasil wawancara dengan salah satu masyarakat lokal yang ada di Kampung Wisata Kreatif Dago Pojok yaitu Ibu Yuyun salah seorang pemilik warung makan, mengatakan "kesulitan yang dilalui saat ini yah karena sekarang Kampung Kreatif ini udah enggak dipegang sama Kang Rahmat lagi. Semenjak ganti pengurus, udah nggak banyak tamu lagi yang datang. Pendapatan yang didapat berkurang".

Berbeda halnya dengan ungkapan Bapak Rahmat Jabaril selaku penggagas. Kepengurusan sekarang tidak berjalan dengan baik karena sebagian besar dari pengurus Kampung Wisata Kreatif Dago Pojok sudah menikah dan memilih pindah dari wilayah ini ke wilayah yang cukup jauh, sehingga tidak dapat maksimal dalam mengurus Kampung Wisata Kreatif Dago Pojok.

Berdasarkan ungkapan dari beberapa informan tersebut, tampak hambatan yang dialami dalam menjalankan aktivitas pariwisata di Kampung Wisata Kreatif Dago Pojok beragam, mulai dari tidak adanya bantuan berupa dari pemerintah dan kepengurusan kampung wisata kreatif saat ini berjalan dengan buruk sehingga terjadi penurunan kunjungan wisatawan.

3. Hasil Analisa Tingkat Partisipasi Masyarakat di Kampung Wisata Kreatif Dago Pojok

Berdasarkan hasil pemaparan dari keempat aspek data diatas, hasil analisa tingkat partisipasi masyarakat Kampung Wisata Kreatif Dago Pojok kemudian dibagi kedalam empat kategori melalui penyempitan kedelapan tingkat partisipasi oleh Chougill (1996). Adapun keempat kategori tersebut adalah sebagai berikut:

a. Support (Mendukung Masyarakat) 
Tingkat partisipasi masyarakat yang masuk kedalam kategori ini adalah tingkat pemberdayaan, kemitraan, dan konsiliasi. Pada kategori ini Kampung Wisata Kreatif Dago Pojok berada pada tingkat pemberdayaan. Masyarakat lokal melompati tingkat kemitraan dan tingkat konsiliasi. Karena pada kedua tingkatan ini menjelaskan adanaya keterlibatan pemerintah pada kampung wisata kreatif saat mengalami permasalahan. Berdasarkan hasil wawancara yang dilakukan dengan penggagas kampung dan Ketua RT, belum ada masalah yang terjadi terkait adanya kerjasama dengan komunitas lain. Kebenarannya adalah masyarakat lokal sangat mengharapkan adanya bantuan dari pihak pemerintah dalam pengembangannya. Namun pemerintah malah sebaliknya. Pemerintah mengharapkan agar masyarakat Kampung Wisata Kreatif Dago Pojok memulai perbaikan pada diri mereka sendiri. Pemerintah ingin Kampung Wisata Kreatif Dago Pojok dapat berkembang dengan memberdayakan masyarakat lokalnya. Pemerdayaan tersebut dapat berupa mampu bekerjasama dengan berbagai komunitas sehingga masyarakat memegang kendali sepenuhnya dalam aktivitas pariwisata yang ada di Kampung Wisata Kreatif Dago Pojok. Sehingga dapat disimpulkan bahwa dalam kategori ini, masyarakat lokal sudah berada pada tingkat pertama yaitu tingkat pemberdayaan.

b. Manipulation (Memanipulasi Masyarakat)

Tingkat partisipasi masyarakat yang termasuk kedalam kategori ini adalah tingkat disimulasi, diplomasi, dan menginformasikan. Berdasarkan temuan dilapangan, partisipasi masyarakat di Kampung Wisata Kreatif Dago Pojok dalam kategori ini masuk pada tingkat diplomasi. Awal pembentukkannya, kampung wisata kreatif ini berdiri karena inisiatif masyarakat lokal yang mengharapkan adanya bantuan pemerintah. Namun, pada pengembangannya pemerintah hanya sebagai pemberi dukungan moril tanpa adanya dukungan material. Pemerintah hanya sekedar merekomendasikan kampung wisata kreatif kepada wisatawan yang akan berkunjung sehingga kemudian masyarakat mendapatkan keuntungan melalui datangnya wisatawan dari pemerintah tersebut. Tingkat diplomasi juga menjelaskan bahwa pemerintah hanya sekedar melakukan kunjungan ke kampung wisata dan bertemu dengan masyarakat agar masyarakat merasa pemerintah peduli dengan kampung wisata kreatif ini.

\section{c. Rejection (Penolakan Masyarakat)}

Tingkat partisipasi yang termasuk dalam kategori ini hanya satu yaitu tingkat konspirasi. Berdasarkan hasil penelitian yang sudah dilakukan, pemerintah tidak ada melakukan penolakan tetapi menerima dengan baik adanya gagasan pembentukan kampung wisata kreatif. Sehingga partisipasi masyarakat tidak ada dalam kategori ini. d. Neglect (Mengabaikan Masyarakat)

Tingkat partisipasi yang termasuk dalam kategori ini juga hanya ada satu tingkat saja yaitu tingkat manajemen diri. Pada tingkat ini berdasarkan hasil analisa adalah pembentukan kampung wisata kreatif yang dikembangakan atas dasar inisiatif masyarakat lokal yang menginginkan perubahan dari segi ekonomi dan budaya. Pada segi ekonomi, masyarakat mengharapkan bahwa dengan adanya kampung wisata kreatif ini dapat meningkatkan perekonomian masyarakat lokal. Sedangkan pada segi budaya masyarakat lokal ingin tetap menjaga kebudayaan lokal agar tetap terjaga eksistensinya. Sehingga dalam pembangunan kampung wisata kreatif ini, tidak ada keterlibatan pemerintah sama sekali. Pemerintah hanya sebagai penerima konsep yang kemudian meresmikannya sebagai daya tarik wisata saja.

Berdasarkan hasil analisa bahwa partisipasi masyarakat lokal di Kampung Wisata Kreatif Dago Pojok berada pada tingkatan paling atas yaitu tingkat pemberdayaan. Tetapi untuk mencapai tingkatan tersebut, partisipasi masyarakat juga berbeda dalam setiap kategorinya. Berdasarkan keempat kategori, kategori pertama partisipasi masyarakat paling banyak berada pada tingkat pemberdayaan. Pada kategori kedua partisipasi masyarakat berada di tingkat diplomasi karena pemerintah terlihat hanya sekedar memberi kepedulian tanpa adanya tindak lanjut seperti yang diharapkan oleh masyarakatnya. Partisipasi masyarakat tidak masuk sama sekali pada kategori ketiga. Pada kategori keempat, partisipasi masyarakat terlihat pada keinginan masyarakat untuk perubahan yang lebih baik dan pemerintah tidak ikut terlibat dalam mengagas maupun pembentukan Kampung Wisata Kreatif Dago Pojok.

\section{SIMPULAN DAN SARAN}

Kondisi pariwisata yang terjadi saat ini di Kampung Wisata Kreatif Dago Pojok sudah cukup memadai ditinjau melalui komponen produk pariwisata (4A). Atraksi wisata yang teerdapat di Kampung Wisata Kreatif Dago Pojok sangat beragam yaitu mural, kesenian berupa pencak silat, jaipongan, dagung, kuda lumping, karinding dan calung, event dan workshop, sanggar wayang golek, alat musik tradisional berupa, celempunhgan, keprak dan guludug, dan permainan tradisional berupa pepletokan, perepet jengkol, dan galah jidar. Fasilitas yang dimiliki berpa 4 buah homestay, tilet, masjid, lapangan pertunjukan dan lahan parkir. Adapun aksesibilitas ke kampung wisata kreatif dapat menggunakan kendaraan umum dan kendaraan pribadi. Letaknya yang strategis berada di tengah kota. Namun, harus memperbaiki 
jalanan menuju gang. Adapun dari aspek ancillary, Kampung Wisata Kreatif Dago Pojok sudah memiliki lembaga atau organisasi kepengurusan yang anggotanya merupakan masyarakat lokal kampung wista ini. Tetapi banyak dari pengurus tersebut terutama ketuanya sendiri sudah meniukah dan memilih untuk tinggal di tempat lain, sehingga kepengurusan kampung wisata menjadi terbengkalai.

Partisipasi masyarakat lokal di Kampung Wisata Kreatif Dago Pojok berada pada tingkatan paling atas yaitu tingkat pemberdayaan. Tetapi untuk mencapai tingkatan tersebut, partisipasi masyarakat juga berbeda dalam setiap kategorinya. Berdasarkan keempat kategori, kategori pertama partisipasi masyarakat paling banyak berada pada tingkat pemberdayaan. Pada kategori kedua partisipasi masyarakat berada di tingkat diplomasi karena pemerintah terlihat hanya sekedar memberikan kepedulian tanpa adanya tindak lanjut seperti yang diharapkan oleh masyarakatnya. Partisipasi masyarakat tidak masuk sama sekali pada kategori ketiga. Pada kategori keempat, partisipasi masyarakat terlihat pada keinginan masyarakat untuk perubahan yang lebih baik dan pemerintah tidak ikut terlibat dalam mengagas maupun pembentukan Kampung Wisata Kreatif Dago Pojok.

\section{DAFTAR PUSTAKA}

Arikunto, S. 2006. Prosedur Penelitian Suatu Pendekatan Praktik Edisi Revisi VI. Jakarta: PT. Rineka Cipta

Arnstein, S. R. 1969. A Ladder of Citizen Participation dalam Journal of the American Planning Association, 35:4, 216224. London: Routledge

Badan Pusat Statistik Kota Bandung. 2018. Kecamatan Coblong Dalam Angka 2018. Bandung

Chairunnisa, D. 2012. Perencanaan Kampung Wisata Dago Pojok Sebagai Wisata Kreatif Berbasis Komunitas Lokal Di Kota Bandung. Bandung. Universitas Pendidikan Indonesia

Chougill, M. B. G. 1996. A Ladder of Community Participation for Underdeveloped Countries. UK: University of Sheffield

Cooper, Chris, et al. 1998. Tourism Principles and Practice (2nd ed.) London: Prentice Hall.

Cresswell, J. W. 2012. Research Design Pendekatan Kualitatif, Kuantitatif dan Mixed Cetakan ke-2. Yogyakarta: Pustaka Pelajar.

Damanik, J dan Frans Teguh, 2013. Manajemen Destinasi Pariwisata (Edisi Revisi). Yogyakarta: Kepel Press.

Mahagangga, I Gusti Agung Oka. 2018. Kelompok Sadar Wisata (Pokdarwis) dan Desa Wisata.
Makalah Presentasi Pengabdian Kepada Masyarakat Prodi S3 Pariwisata Universitas Udayana, di Desa Batuan, Kecamatan Sukawati, Kabupaten Gianyar, Provinsi Bali 31 Agustus 2018. DOI: 10.131/RG.2.2.28167.01443

Marysya, P. 2017. Tingkat Partisipasi Masyarakat Dalam Pengelolaan Wisata Berbasis Potensi Desa Di Kampung Wisata Situ Gede Bogor. Bogor. IPB

Murdiyanto, E. 2011. Partisipasi Masyarakat Dalam Pengembangan Desa Wisata Karanggeng, Prwobinangun, Pakem, Sleman. Jurnal SEPA Vol. 7 No. 2. Yogyakarta

Paramita, 2015. Identifikasi Tingkat Partisipasi Masyarakat Studi Kasus Kampung Lorotan, Kelurahan Kota Lama, Kota Malang. Jurnal Kawistara Vol. 5 No. 3. Universitas Gajah Mada

Raras, M. K. H. 2016. Pengaruh Kegiatan Wisata Kampung Kreatif Terhadap Pengubahan Tataan Ruang Kegiatan Dan Perubahan Tatanan Spasial Kampung Dago PojokBandung. Bandung. Universitas Katolik Parhayangan

Sugiyono. 2010. Metode Penelitian Pendidikan (Pendekatan Kuantitatif, Kualitatif dan $R \&$ D). Bandung: Alfabeta.

Sumber lain:

Undang-Undang No 10 Tahun 2009 Tentang Kepariwisataan

https://tempatwisatadibandunginfo/kampungwisata-kreatif-dagopojokbandung/\#Kampung_Wisata_Kreatif_ Dago_Pojok_Bandung 